A. P. Osmachko스, A. M. Kovaleva ${ }^{1}$, T. V. Ilyina ${ }^{1}$, N. V. Kashpur ${ }^{2}$, O. M. Koshovyi ${ }^{1}$, A. M. Komisarenko ${ }^{1}$

${ }^{1}$ National University of Pharmacy

${ }^{2}$ State Institution "Institute of Microbiology and Immunology named after I. I. Mechnikov, National Academy of Medical Sciences of Ukraine

\title{
The study of the chemical composition and the immunomodulatory activity of polysaccharide complexes from Veronica teucrium L.
}

Aim. To determine and study the qualitative composition and the quantitative content of polysaccharide complexes (PsC) of $V$. teucrium flowers, leaves and rhizomes, as well as their effect on the transformation and functional activity of macrophages and their hematogenic precursors.

Materials and methods. The PsC of V. teucrium flowers, leaves and rhizomes were obtained by multiple extraction of the plant raw material with water when heating and with the subsequent concentration of combined extracts and their precipitation. Monosaccharides of PsC hydrolyzates were studied by the methods of paper chromatography and spectrophotometry. The immunomodulatory activity of PsC of $\mathrm{V}$. teucrium flowers, leaves and rhizomes was studied in vitro in the reaction of macrophage transformation of mononuclear cells of the peripheral blood.

Results and discussion. The yield of the complexes is as follows: in flowers $-8.40 \%$, in leaves $-5.30 \%$, in rhizomes $-1.95 \%$. The qualitative composition and the quantitative content of monosaccharides in the complexes have been determined, and the hydrolysis kinetics of the components has been studied. The results of the in vitro study of the effect of PsC of V. teucrium flowers, leaves and rhizomes on transformation and the functional activity of immune competent cells of the peripheral blood are presented.

Conclusions. The yield of polysaccharide complexes of $V$. teucrium is as follows: in flowers $-8.40 \%$, in leaves $5.30 \%$, in rhizomes $-1.95 \%$. Monosaccharides of PsC in flowers are presented by galactose, glucose, fructose, arabinose and xylose; in leaves - by glucose and arabinose, there is galactose, fructose, xylose in a minor amount; in rhizomes there is mainly glucose. It has been found that the optimal time for hydrolysis for PsC in flowers and leaves is $60 \mathrm{~min}$; in rhizomes - $150 \mathrm{~min}$. It has been determined that the $\mathrm{PsC}$ studied in the dose of $50 \mu \mathrm{g} / \mathrm{ml}$ maximally stimulate the functional activity of immune competent cells; the PsC of $V$. teucrium flowers in the dose range from 5 to $100 \mu \mathrm{g} / \mathrm{ml}$ possesses the more expressed immunomodulatory activity.

Key words: Veronica teucrium L.; polysaccharide complexes; immunomodulatory activity

А. П. Осьмачко, А. М. Ковальова, Т. В. Ільїна, Н. В. Кашпур, О. М. Кошовий, А. М. Комісаренко Дослідження хімічного складу та імуномодулюючої активності полісахаридних комплексів Вероніки широколистої (Veronica teucrium L.)

Мета роботи - одержання, дослідження якісного складу та кількісного вмісту полісахаридних комплексів (ПК) квіток, листя та кореневищ Вероніки широколистої і вивчення їх впливу на трансформаційну і функціональну активність макрофагів та їх гематогенних попередників.

Матеріали та методи. ПК квіток, листя та кореневищ Вероніки широколистої, отримані шляхом багаторазової екстракції рослинної сировини водою при нагріванні з наступним концентруванням об'єднаних витяжок та їх осадженням. Моноцукри гідролізату ПК досліджували методом паперової хроматографії та методом спектрофотометрії. Імуномодулюючу активність ПК квіток, листя та кореневищ Вероніки широколистої вивчали in vitro за реакцією макрофрагальної трансформації мононуклеарів периферичної крові.

Результати та їх обговорення. Вихід комплексів становить: з квіток - 8,40 \%, з листя - 5,30 \%, 3 кореневищ - 1,95\%. Встановлено якісний склад та визначено кількісний вміст моноцукрів у комплексах, досліджено кінетику гідролізу компонентів. Наведені результати вивчення in vitro впливу полісахаридних комплексів квіток, листя та кореневищ Вероніки широколистої на трансформаційну та функціональну активність імунокомпетентних клітин перифреричної крові.

Висновки. Вихід полісахаридних комплексів з Вероніки широколистої становить: з квіток - 8,40 \%, 3 листя 5,30 \%, з кореневищ - 1,95 \%. Моноцукри ПК квіток представлені галактозою, глюкозою, фрруктозою, арабінозою та ксилозою; листя - глюкозою та арабінозою, в мінорній кількості присутні: галактоза, фруктоза, ксилоза; кореневищ - переважно глюкозою. Визначено оптимальний термін гідролізу для ПК квіток та листя - 60 хв; для ПК кореневищ - 150 хв. Встановлено, що досліджувані комплекси у дозі 50 мкг/мл максимально стимулюють функціональну активність імунокомпетентних клітин; полісахаридний комплекс квіток Вероніки широколистої проявляє більш виражену імуномодулюючу дію у дозі від 5 до 100 мкг/мл.

Ключові слова: Вероніка широколиста; полісахаридні комплекси; імуномодулююча активність 
А. П. Осьмачко, А. М. Ковалева, Т. В. Ильина, Н. В. Кашпур, О. Н. Кошевой, А. Н. Комиссаренко

\section{Исследование химического состава и иммуномодулирующей активности} полисахаридных комплексов Вероники широколистной (Veronica teucrium L.)

Цель работы - получение, исследование качественного состава и количественного содержания полисахаридных комплексов (ПК) цветков, листьев и корневищ Вероники широколистой и изучение их влияния на трансформационную и функциональную активность макрофагов и их гематогенных предшественников.

Материалы и методы. ПК цветков, листьев и корневищ Вероники широколистой, полученные путем многократной экстракции растительного сырья водой при нагревании с последующим концентрированием объединенных вытяжек и их осаждением. Моносахара гидролизатов ПК исследовали методом бумажной хроматографии и методом спектрофотометрии. Иммуномодулирующую активность ПК цветков, листьев и корневищ Вероники широколистой изучали in vitro с помощью реакции макрофагальной трансформации мононуклеаров периферической крови.

Результаты и их обсуждение. Выход комплексов составляет: из цветков - 8,40 \%, из листьев - 5,30 \%, из корневищ - 1,95 \%. Установлен качественный состав и определено количественное содержание моносахаров в комплексах, исследована кинетика гидролиза компонентов. Приведенные результаты изучения in vitro влияния полисахаридных комплексов цветков, листьев и корневищ Вероники широколистой на трансформационную и функциональную активность иммунокомпетентных клеток периферической крови.

Выводы. Выход полисахаридных комплексов из Вероники широколистой составляет: из цветков - 8,40 \%, из листьев - 5,30 \%, из корневищ - 1,95 \%. Моносахара ПК цветков представлены галактозой, глюкозой, фрруктозой, арабинозой и ксилозой; листьев - глюкозой и арабинозой, в минорном количестве присутствуют галактоза, фруктоза, ксилоза; корневищ - преимущественно глюкозой. Определено оптимальное время гидролиза для ПК цветков и листьев - 60 мин; для ПК корневищ -- 150 мин. Установлено, что полученные комплексы в дозе 50 мкг/мл максимально стимулируют функциональную активность иммунокомпетентных клеток; полисахаридный комплекс цветков Вероники широколистой проявляет более выраженное иммуномодулирующее действие в дозах от 5 до 100 мкг/мл.

Ключевые слова: Вероника широколистая; полисахаридные комплексы; иммуномодулирующая активность

The problem of searching and developing effective drugs of the plant origin with the immunomodulatory activity is important for the pharmaceutical science today.

Immunomodulatory drugs of the plant origin have several advantages: they act physiologically and mildly, have low toxicity or almost not toxic, do not accumulate in the body, have a wide therapeutic range, as well as due to biological active substances (BAS) are able to provide a multi-faceted effect - antibacterial, anti-inflammatory, sedative, antiviral, antitoxic, expectorant, wound healing, etc. $[1,2]$.

Therefore, development of drugs of the plant origin that affect the immune processes for prevention, treatment and rehabilitation [3] is a topical issue.

At the pharmaceutical market of Ukraine there is a limited number of herbal drugs that affect the immune processes, including the well-known drugs from Echinacea purpurea (L.) Moench and Echinacea angustifolia DC., medicines containing polysaccharides with the immunostimulating effect (Echinacea NSP, Immunal ${ }^{\circledR}$, Prodyhiozan; Zymosan) [4, 5].

Veronica broadleaf (Veronica teucrium L.) is a perennial plant of the family Plantaginaceae Juss. with a wide area of distribution on the Ukrainian territory and is grown as an ornamental plant. Species is unofficial, and widely used in folk medicine of many countries as an expectorant, anti-inflammatory, antiseptic, hemostatic, choleretic, analgesic drug. The herb of $V$. teucrium is used commonly in such dosage forms as alcoholic tinctures and infusions, much more rarely a decoction of its rhizomes, which presumably contains polysaccharides, is used [6].

The aim of this research was to study the qualitative composition and the quantitative content of poly- saccharide complexes (PsC) of V. teucrium flowers, leaves and rhizomes, as well as their effect on transformation and the functional activity of macrophages and their hematogenic precursors.

\section{Materials and methods}

The PsC of V.teucrium flowers, leaves and rhizomes were obtained by multiple extraction of the air-dry plant raw material with water [8] when heating $\left(60^{\circ} \mathrm{C}\right)$, in the raw material : extractant ratio $(1: 18-1: 27)$ with the subsequent concentration of combined extracts and treatment with $96 \%$ ethanol.

To conduct the acid hydrolysis $6 \mathrm{ml}$ of purified water and $10 \mathrm{ml}$ of sulfuric acid were added to $4.0 \mathrm{ml}$ of $1 \%$ of solution of the raw material $\mathrm{PsC}$ in a $25 \mathrm{ml}$ volumetric flask, samples were taken in every $30 \mathrm{~min}$ for determining the time of hydrolysis. After cooling the solutions were quantitatively transferred in a volumetric flask, diluted to $25 \mathrm{ml}$ with water; $5 \mathrm{ml}$ of the solution obtained was neutralized with $20 \%$ solution of sodium hydroxide by the universal indicator (Solution A).

Monosaccharides of the hydrolyzate were studied by the method of paper chromatography. The chromatographic conditions were as follows: a chromatographic paper "Filtrak" (FN-12); the system of solvents $-n$-butanol - acetic acid - water $(4: 1: 2)$; UV-light $(\lambda=354 \mathrm{~nm})$; a developer reagent - aniline ftalate; the heating temperature of the chromatogram processed $-100-105^{\circ} \mathrm{C}$. As standards $0.1 \%$ solutions of such authentic substances as xylose, mannose, arabinose, fructose, glucose, galactose and maltose were used. Sugars were identified by coloration after development, by fluorescence in UVlight, by $\mathrm{R}_{\mathrm{f}}$ value compared to the samples of authentic substances (Tab. 1). 
Table 1 tain galactose, glucose, fructose, arabinose and xylose;

Determination of the monomeric composition of PsC from $V$. teucrium L.

\begin{tabular}{|c|c|c|c|}
\hline$R_{f}$ & Standard $R_{f}$ & $\begin{array}{c}\text { Identified } \\
\text { monosaccharide } \\
\text { Galactose }\end{array}$ & Part of the plant \\
\hline 0.21 & 0.21 & Flowers, leaves* \\
\hline 0.23 & 0.23 & Glucose & $\begin{array}{c}\text { Leaves, flowers, } \\
\text { rhizomes }\end{array}$ \\
\hline 0.27 & 0.27 & Fructose & Flowers, leaves* \\
\hline 0.30 & 0.30 & Arabinose & Flowers, leaves \\
\hline 0.34 & 0.34 & Xylose & Flowers, leaves* \\
\hline
\end{tabular}

Note. ${ }^{*}$ - a minor amount of the substance.

Determination the quantitative content of monosaccharides in the polysaccharide complexes obtained calculated with reference to glucose was performed by spectrophotometry. An Evolution 60S spectrophotometer (USA) was used at the analytical wavelength $\lambda=463 \mathrm{~nm}$.

For the spectrophotometric study Solution A was transferred in a $25 \mathrm{ml}$ volumetric flask, diluted with water to the volume (Solution B). In a $25 \mathrm{ml}$ volumetric flask $1 \mathrm{ml}$ of $1 \%$ picric acid, $3 \mathrm{ml}$ of $20 \%$ solution of sodium carbonate, $1 \mathrm{ml}$ of Solution B, $10 \mathrm{ml}$ of purified water were added, then heated at $100{ }^{\circ} \mathrm{C}$ for $20 \mathrm{~min}$, and after cooling diluted with water to the volume. In parallel, under the same conditions, the study was performed with $2 \mathrm{ml}$ of the standard solution of glucose and the reference solution.

The immunomodulatory activity of PsC of $V$. teucrium flowers, leaves and rhizomes was studied in vitro in the reaction of macrophage transformation of mononuclear cells of the peripheral blood [7, 9, 10, 11, 12]. The primary cultures of immune competent cells from blood donors were treated with heparin and obtained by sedimentation at $4-8{ }^{\circ} \mathrm{C}$. Blood mononuclear cells were cultured in the nutrient medium 199 with $10 \%$ fetal serum. Sodium salt of benzyl penicillin and streptomycin in the concentration of $100 \mathrm{IU} / \mathrm{cm}$, and amphotericin B were added to the nutrient medium. $\mathrm{PsC}$ were placed to the primary cultures of immune competent cells in the doses of $5 \mu \mathrm{g} / \mathrm{ml}, 50 \mu \mathrm{g} / \mathrm{ml}$ and $100 \mu \mathrm{g} / \mathrm{ml}$, and incubated at $37{ }^{\circ} \mathrm{C}$ for 23 hours. To assess the phagocytic activity of macrophages and their precursors after finishing the cultivation the inactivated reference strain of Staphylococcus aureus-209 P was introduced into the culture.

The immunomodulatory activity of $\mathrm{PsC}$ on immune competent cells was assessed according to the index of macrophage transformation of mononuclear cells (IMTM), the phagocytic index (FI) and the phagocytic number (FN).

The control included the setting of the reaction of macrophage transformation of the peripheral blood mononuclear cells without addition of the substances studied. The experiments were carried out five times. The data obtained were processed statistically [13].

\section{Results and discussion}

The chromatographic analysis of the hydrolyzate has determined that monosaccharides of PsC in flowers con- in leaves - glucose and arabinose, in a minor amount there is galactose, fructose, xylose; in rhizomes there is mainly glucose (Tab. 1); mannose and maltose have not been found.

The yield of the targeted complexes is as follows: in flowers $-8.40 \%$, in leaves $-5.30 \%$, in rhizomes $-1.95 \%$.

When studying the hydrolysis kinetics it has been experimentally found that the time of hydrolysis of $\mathrm{PsC}$ in flowers and leaves can be considered to be $60 \mathrm{~min}$, and the content of monosaccharides of PsC calculated with reference to glucose is in flowers $-36.51 \%$, in leaves $-12.54 \%$, in rhizomes $-8.76 \%$ (Fig.). The time of hydrolysis for PsC in rhizomes is $150 \mathrm{~min}$ since the content of monosaccharides is $12.35 \%(\mathrm{~m}=5, \mathrm{P}=0.95)$.

The decrease was observed at 90 and $120 \mathrm{~min}$, while at $150 \mathrm{~min}$ there was a slight increase of the content of hydrolysis products - monosaccharides, except for PsC in leaves. This is due to different qualitative composition of polysaccharides in generative and vegetative plant organs; the presence of heteropolysaccharides in rhizomes requires more stringent conditions of hydrolysis. In PsC of flowers the sharp increase of monosaccharides at 150 min of the hydrolysis indicates the presence of heteropolysaccharides with the similar structure in flowers and in rhizomes.

Based on the fact that free monosaccharides predominate in complexes of flowers and leaves it can be assumed that the increase of the hydrolysis time as the result of the intramolecular dehydration of monosaccharide molecules leads to formation of such degradation products as hydroxyacetyl furan, furfural and hydroxymethylfurfural, which further produce levulinic, formic, lactic, acetic, etc., acids. This process is possible with high or prolonged temperature processing and the low concentration of monosaccharides.

At higher concentrations of monosaccharides the modification of $\mathrm{PsC}$ components is possible (approximately $5 \%$ of products), namely the reversible reactions of monosaccharide reversion with formation of disaccharides and more rarely oligosaccharides; it is observed in the hydrolysis of $\mathrm{f} \mathrm{PsC}$ in flowers.

Therefore, it is appropriate to determine the content of monosaccharides in PsC after the acid hydrolysis for $60 \mathrm{~min}$.

Introduction of the $\mathrm{PsC}$ of $V$. teucrium flowers to the primary cultures of immune competent cells in the dose of $5 \mu \mathrm{g} / \mathrm{ml}$ caused the increase in IMTM by $20.01 \%$, FI by $-22.13 \%$, and FN by $-50.05 \%$ compared to the intact control (Tab. 2). PsC in leaves increased IMTM by $6.37 \%$, FI by $-21.01 \%$, but decreased FN by $0.42 \%$. PsC in rhizomes increased IMTM by $28.21 \%$, FI by $9.15 \%$, and $\mathrm{FN}$ by $-13.21 \%$.

When using the substances in the dose of $50 \mu \mathrm{g} / \mathrm{ml}$ the maximal stimulation of the functional activity of immune competent cells was observed, except the phagocytic number of $\mathrm{PsC}$ in rhizomes.

Thus, $\mathrm{PsC}$ in flowers increased IMTM by $70.26 \%$, FI - by $48.34 \%$ and FN - by $66.17 \%$ compared to the intact control. PsC in leaves increased IMTM of cells 


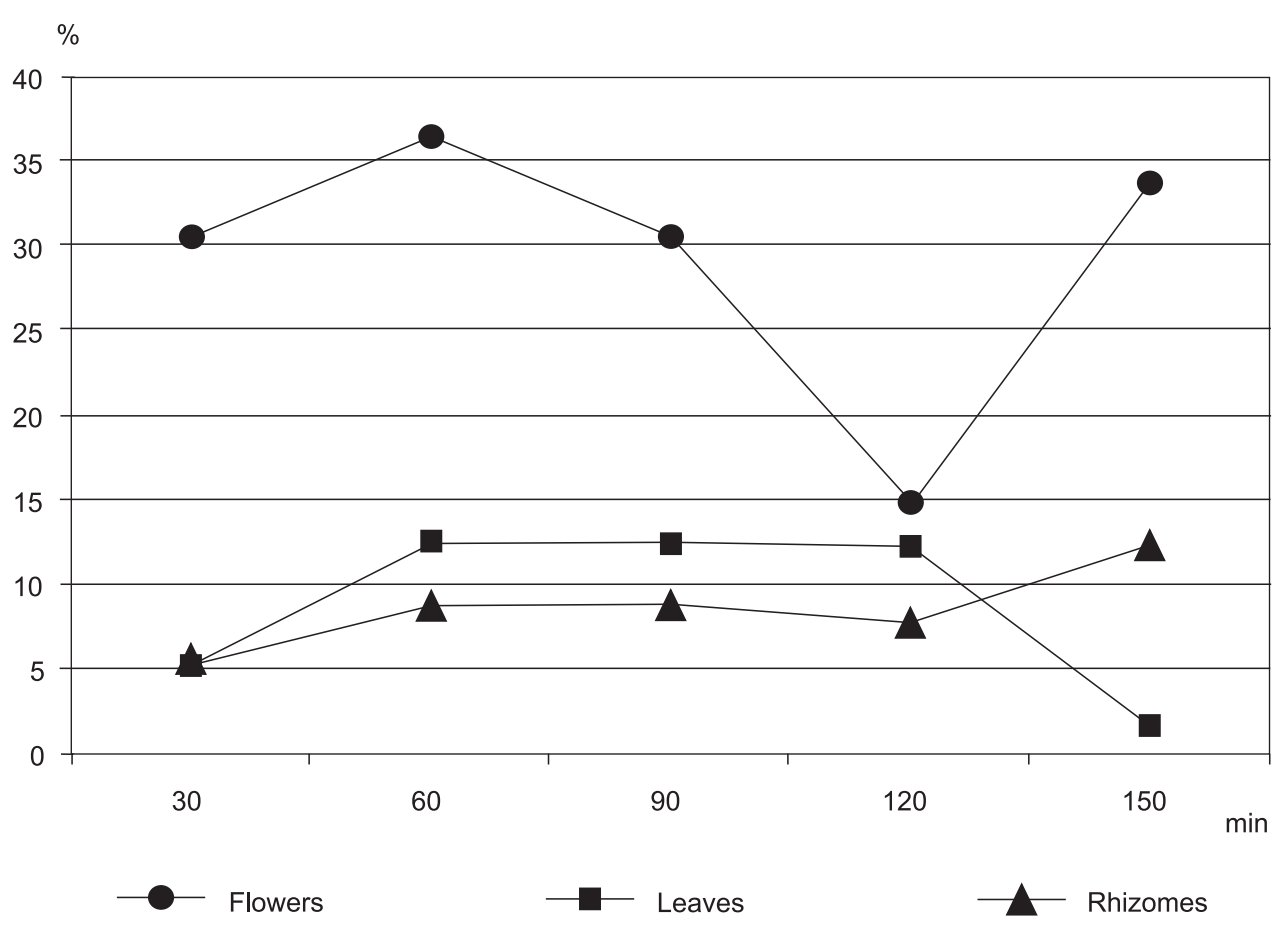

Fig. The hydrolysis kinetics of PsC of Veronica teucrium L.

by $57.19 \%$, FI - by $18.22 \%$, and FN - by $39.04 \%$. In turn, PsC in rhizomes increased IMTM of cells by $69.02 \%$, FI - by $39.04 \%$, and FN - by $22.09 \%$.

The increase of the dose of the substances studied to $100 \mu \mathrm{g} / \mathrm{ml}$ resulted in the decrease of indexes of transformation and the phagocytic activity of macrophages and their precursors compared to the indexes of the sub-

Table 2

The effect of PsC of V. teucrium flowers, leaves and rhizomes on the indexes of macrophage transformation and the phagocytic activity of macrophages and their hematogenic precursors, $\mathrm{n}=5$

\begin{tabular}{|c|c|c|c|c|}
\hline PsC & 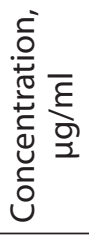 & IMTM, \% & $\mathrm{Fl}, \%$ & $\mathrm{FN}, \%$ \\
\hline \multirow{3}{*}{ Flowers } & 5 & $39.0 \pm 3.2$ & $56.4 \pm 4.0$ & $11.4 \pm 1.3$ \\
\hline & 50 & $55.3 \pm 3.1^{*}$ & $68.6 \pm 3.1^{*}$ & $12.6 \pm 1.5^{*}$ \\
\hline & 100 & $52.7 \pm 4.1$ & $62.8 \pm 2.4$ & $9.3 \pm 0.5$ \\
\hline \multirow{3}{*}{ Leaves } & 5 & $34.7 \pm 4.0$ & $46.2 \pm 2.2$ & $9.2 \pm 0.3$ \\
\hline & 50 & $51.3 \pm 4.3^{*}$ & $54.7 \pm 2.2^{*}$ & $10.6 \pm 1.3^{*}$ \\
\hline & 100 & $34.9 \pm 3.8$ & $46.8 \pm 2.5$ & $9.3 \pm 0.5$ \\
\hline \multirow{3}{*}{ Rhizomes } & 5 & $41.7 \pm 2.3$ & $50.5 \pm 4.2$ & $8.6 \pm 0.6$ \\
\hline & 50 & $55.2 \pm 2.3^{*}$ & $64.4 \pm 3.7^{*}$ & $9.3 \pm 0.5$ \\
\hline & 100 & $46.8 \pm 2.6$ & $62.3 \pm 3.7$ & $11.7 \pm 1.3^{*}$ \\
\hline Control & - & $32.6 \pm 3.4$ & $46.4 \pm 2.8$ & $7.6 \pm 0.6$ \\
\hline
\end{tabular}

Note: ${ }^{*}-\mathrm{P}<0.05$ compared to the intact control. stances in the dose of $50 \mu \mathrm{g} / \mathrm{ml}$, except the phagocytic number of $\mathrm{PsC}$ in rhizomes, for which maximum stimulation was observed. Thus, PsC in flowers increased IMTM of cells by $62.03 \%$, FI - by $35.41 \%$, and FN - by $22.11 \%$ compared to the intact control. PsC in leaves increased IMTM of cells by $7.03 \%$, FI - by $1.07 \%$, and FN - by $22.03 \%$. In turn, PsC in rhizomes increased IMTM of cells by $44.35 \%$, FI - by $34.17 \%$, and FN - by $54.28 \%$.

On the average the maximal stimulation of the functional activity of immune competent cells was observed when using the substances studied in the dose of $50 \mu \mathrm{g} / \mathrm{ml}$.

Therefore, PsC of $V$. teucrium flowers, leaves and rhizomes have shown a dose-dependent stimulatory effect on the transformation and phagocytic activity of macrophages and their mononuclear precursors. The comparative evaluation of the activity of the PsC of $V$. teucrium studied has shown that PsC in flowers possess a more expressed immunomodulatory activity in the dose range from 5 to $100 \mu \mathrm{g} / \mathrm{ml}$.

The data obtained confirm the advisability of further in-depth studies of these substances in finding new ways and principles of correction of immunodeficiency.

CONCLUSIONS

Polysaccharide complexes of $V$. teucrium have been obtained; the yield of PsC is as follows: in flowers $8.40 \%$, in leaves $-5.30 \%$, in rhizomes $-1.95 \%$. It has been determined that monosaccharides of PsC in flowers are presented by galactose, glucose, fructose, arabinose and xylose; in leaves - by glucose and arabinose, there is galactose, fructose, xylose in a minor amount; in rhizomes there is mainly glucose. According to the results of the study of the hydrolysis kinetics has been found that the optimal time for hydrolysis for PsC in flowers and leaves is $60 \mathrm{~min}$; in rhizomes $-150 \mathrm{~min}$. 
The results of the study have shown that $\mathrm{PsC}$ of $V$. teucrium flowers, leaves and rhizomes have a pronounced stimulatory effect on the transformation activity of immune competent blood cells. It has been determined that the PsC studied in the dose of $50 \mu \mathrm{g} / \mathrm{ml}$ maximally stimulate the functional activity of immune competent cells; the $\mathrm{PsC}$ of $V$. teucrium flowers in the dose range from 5 to $100 \mu \mathrm{g} / \mathrm{ml}$ possesses the more expressed immunomodulatory activity.

Conflict of Interests: authors have no conflict of interests to declare.

\section{REFERENCES}

1. Гарник, Т. П. Стан системи фагоцитуючих макрофагів у хворих з синдромом хронічної втоми при лікуванні препаратами рослинного походження депривітом та імуноплюсом / Т. П. Гарник, В. М. Фролов, Н. А. Пересадін / Укр. мед. альманах. - 2008. T. 11, № 6. - С. 53-57.

2. Осьмачко, А. П. Перспективи використання рослин родів Veronica, Artemisia та Lamium як антибактеріальних засобів / А. П. Осьмачко, А. М. Ковальова // Ліки - людині. Сучасні проблеми фармакотерапії і призначення лікарських засобів : матер. XXXIII Всеукр. наук.-практ. конф. за міжнар. участі, 8 квітня 2016 р. - Х. : НФаУ, 2016. - 97 с.

3. Воробьев, А. А. Принципы классификации и стратегии применения иммуномодуляторов в медицине / А. А. Воробьев // Журн. микробиол., эпидемиол. и иммунол. - 2002. - № 4 (25). - С. 93-98.

4. Компендиум 2015 - лекарственные препараты / под ред. В. Н. Коваленко. - К. : МОРИОН, 2015. - С. К32-33, М12, Л613-617, Л1799-1803, Л1833-1834, С280.

5. Перспективы использования растительных полисахаридов в качестве лечебных и лечебно-профилактических средств / Н. А. Криштанова, М. Ю. Сафонова, В. Ц. Болотова и др. // Вестник ВГУ. - 2005. - № 1. - С. $212-221$.

6. Лікарські рослини : енциклопедичний довідник / відп. ред. А. А. Гродзінський. - К. : Українська Радянська Енциклопедія ім. М. П. Бажана, Олімп, 1992. - С. 84-85.

7. Использование микрометода для бласттрансформации лимфоцитов человека и животных / Е. П. Киселева, А. С. Цвейбах, Е. И. Гольдман, Н. В. Пигарева // Иммунол. - 1985. - № 1. - С. 76-78.

8. Спосіб одержання комплексу полісахаридів з імуномодулюючою активністю. Пат. України на корисну модель МПК (2017.01) А 61 К 36/38, А 61 К 127/00, А 61 К 133/00, А 61 Р 37/02 / А. П. Осьмачко, А. М. Ковальова, Т. В. Ільїна, Н. В. Кашпур, А. М. Комісаренко, О. М. Кошовий, О. В. Горяча, Н. В. Сидора, Н. С. Шемчук, О. В. Гончаров. - № u201701098 ; заявл. 06.02.2017.

9. Kvatchoff, V. G. Application de subculture de leycocytes en test-systeme devalution immunomodule de vims in vitro / V. G. Kvatchoff // Abstracts of V International Congress Cell Biology. - Montreal (Canada), 1988. - 205 p.

10. Доклінічні дослідження лікарських засобів: метод. рек. / за ред. чл.-кор. НАМН України О. В. Стефанова. - К. : Авіценна, 2001. - С. 74-97.

11. Никитин, В. М. Справочник методов иммунологии / В. М. Никитин. - Кишинев : Штиинца, 1982. -304 с.

12. Фролов, В. М. Определение фагоцитарной активности моноцитов периферической крови у больных / В. М. Фролов, Н. А. Пересадин, И. Я. Пшеничный // Лабораторное дело. - 1990. - № 9. - С. 27-29.

13. Statistica. - Available at : http://www.statsoft.com/Products/STATISTICA

\section{REFERENCES}

1. Harnyk, T. P., Frolov, V. M., Peresadin, N. A. (2008). Ukrainskyi medychnyi almanakh, 11 (6), 53-57.

2. Osmachko, A. P., Kovalova, A. M. (2016). Liky - liudyni. Suchasni problemy farmakoterapii i pryznachennia likarskykh zasobiv. Kharkiv: NUPh, 97.

3. Vorobev, A. A. (2002). Zhurnal mikrobiologii, epidemiologii i immunologii, 4 (25), 93-98.

4. Kompendium 2015 - lekarstvennyie preparaty. (2015). Kyiv: MORION, K32-33, M12, L613-617, L1799-1803, L1833-1834, S280.

5. Krishtanova, N. A., Safonova, M. Yu., Bolotova, V. Tc. et. al. (2005). Vestnik VGU, 1, 212-221.

6. Likarski roslyny: entsyklopedychnyi dovidnyk. (1992). Kyiv: Ukrainska Radianska Entsyklopediia im. M. P. Bazhana, Olimp, 84-85.

7. Kiseleva, Ye. P., Tcveibakh, A. S, Goldman, Ye. I., Pigareva, N. V. (1985). Immunologiia, 1, 76-78.

8. Osmachko, A. P., Kovaleva, A. M., Ilina, T. V., Kashpur, N. V., Komisarenko, A. M., Koshovyi, O. M., Horiacha, O. V., Sydora, N. V., Shemchuk, N. S., Honcharov, O. V. (2017). Sposib oderzhannia kompleksu polisakharydiv z imunomoduliuiuchoiu aktyvnistiu. Patent na korysnu model A61K 36/38, A61K 127/00, A61K 133/00, A61P 37/02. № u201701098; declared 06.02.2017.

9. Kvatchoff, V. G. (1988). Application de subculture de leycocytes en test-systeme devalution immunomodule de vims in vitro. Abstracts of V International Congress Cell Biology. Montreal (Canada), 205.

10. Doklinichni doslidzhennia likarskykh zasobiv. (2001). Kyiv: Avitsena, 74-97.

11. Nikitin, V. M. (1982). Spravochnik metodov immunologii. Kishinev: Shtintca, 304.

12. Frolov, V. M., Peresadin, N. A., Pshenichnyi, Y. A. (1990). Laboratornoe delo, 9, 27-29.

13. Statistica. Available at: http://www.statsoft.com/Products/STATISTICA 
Information about authors:

Osmachko A. P., postgraduate student of the Pharmacognosy Department, National University of Pharmacy. E-mail: osmachkoalina5@gmail.com. ORCID: http://orcid.org/0000-0001-9158-204X

Kovaleva A. M., Doctor of Pharmacy (Dr. habil.), professor of the Pharmacognosy Department, National University of Pharmacy. E-mail: allapharm@yahoo.com. ORCID: http://orcid.org/0000-0002-1758-1222

Ilyina T. V., Doctor of Pharmacy (Dr. habil.), associate professor, professor of the Pharmacognosy Department, National University of Pharmacy. ORCID: http://orcid.org/0000-0003-3728-9752

Kashpur N. V., junior research fellow of the Immunorehabilitology Laboratory, State Institution "Institute of Microbiology and Immunology named after I. I. Mechnikov at the National Academy of Medical Sciences of Ukraine

Koshovyi O. M., Doctor of Pharmacy (Dr. habil.), associate professor, head of the Pharmacognosy Department, National University of Pharmacy.

ORCID: http://orcid.org/0000-0001-9545-8548

Komissarenko A. M., Doctor of Pharmacy (Dr. habil.), professor of the Chemistry of Natural Compounds Department, National University of Pharmacy Інформація про авторів:

Осьмачко А. П., аспірант кафедри фармакогнозії, Національний фармацевтичний університет. E-mail: osmachkoalina5@gmail.com.

ORCID: http://orcid.org/0000-0001-9158-204X

Ковальова A. М., д-р фармац. наук, професор кафедри фармакогнозії, Національний фармацевтичний університет. E-mail: allapharm@уаһоо.сот. ORCID: http://orcid.org/0000-0002-1758-1222

Ільїна Т. В., д-р фармац. наук, доцент, професор кафедри фармакогнозії, Національний фармацевтичний університет. ORCID: http://orcid.org/0000-0003-3728-9752 Кашпур Н. В., молодший науковий співробітник лабораторії імунореабілітології ДУ «Інститут мікробіології та імунології ім. І. І. Мечникова» НАМН України Кошовий О. М., д-р фармац. наук, доцент, завідувач кафедри фармакогнозії, Національний фармацевтичний університет. ORCID: http://orcid.org/0000-0001-9545-8548 Комісаренко А. М., д-р фармац. наук, професор кафедри хімії природних сполук, Національний фармацевтичний університет

Информация об авторах:

Осьмачко А. П., аспірант кафедры фармакогнозии, Национальный фармацевтический университет. E-mail: osmachkoalina5@gmail.com. ORCID: http://orcid.org/0000-0001-9158-204X

Ковалева А. М., д-р фармац. наук, профессор кафедры фармакогнозии, Национальный фармацевтический университет. E-mail: allapharm@уahoo.com.

ORCID: http://orcid.org/0000-0002-1758-1222

Ильина Т. В., д-р фармац. наук, доцент, профессор кафедры фармакогнозии, Национальный фармацевтический университет.

ORCID: http://orcid.org/0000-0003-3728-9752

Кашпур Н. В., младший научный сотрудник лаборатории иммунореабилитологии ГУ «Институт микробиологии и иммунологии им. И. И. Мечникова» НАМН Украины

Кошевой О. Н., д-р фармац. наук, доцент, заведующий кафедры фармакогнозии, Национальный фармацевтический университет.

ORCID: http://orcid.org/0000-0001-9545-8548

Комиссаренко А. Н., Д-р фармац. наук, профессор кафедры химии природных соединений, Национальный фармацевтический университет 